\title{
Mitigation of power quality problems using series active filter in a microgrid system
}

\author{
Awais Farooqi ${ }^{1}$, Muhammad Murtadha Othman ${ }^{2}$, Ahmad Farid Abidin $^{3}$, Shahril Irwan Sulaiman ${ }^{4}$, \\ Mohd Amran Mohd Radzi ${ }^{5}$ \\ 1,2,3,4 Faculty of Electrical Engineering, Universiti Teknologi Mara, Malaysia \\ ${ }^{5}$ Departement of Electrical \& Electronic Engineering, Faculty of Engineering, University Putra Malaysia, Malaysia
}

\begin{tabular}{l} 
Article Info \\
\hline Article history: \\
Received Apr 10, 2019 \\
Revised Jul 14, 2019 \\
Accepted Jul 31, 2019 \\
\hline
\end{tabular}

\section{Keywords:}

Dynamic voltage restorer Power quality

Energy storage

Mini-hydro turbine system

\section{Corresponding Author:}

Muhammad Murtadha Othman, Faculty of Electrical Engineering, Universiti Teknologi Mara, 40450 Shah Alam, Selangor, Malaysia. Email:mamat505my@yahoo.com

\begin{abstract}
Dynamic voltage restorer (DVR) is a series active filter device that is used to protect sensitive loads from power quality issues such as voltage sag, swell, harmonics or disturbances. This implies that the DVR is capable to mitigate power quality disturbances at load terminal. Harmonic is a major power quality problem polluting distribution network causing the end-user equipment to fail operating due to the occurrence of disturbances in voltage, current or frequency. This paper discusses on the DVR used as the proposed technique to mitigate the voltage sag and swell in a distribution network connected with energy storage system and mini-hydro turbine system.
\end{abstract}

Copyright (C) 2019 Institute of Advanced Engineering and Science. All rights reserved.

\section{INTRODUCTION}

Environmental pollution and energy crises are becoming increasingly important for the industries to adopt sustainable energy generation methods in a system. In recent years, the utilization of renewable energy resources have become important factors in generating electricity due its cost effectiveness in reducing emissions [1]. However, with the advent of energy conversion systems in renewable resources, power electronic devices plays a major role to improve power quality problems to the end-users through various implementation of control algorithm [2]. The power quality problems are among the crucial factors that has an adverse impact to the business sectors and this occurs due to the massive usage of electronics equipment such as the programmable logic controller (PLC), light emitting diode (LED) and many others [3]. The power quality problems may instigate to a disturbance in distribution network that will deteriorate the economic productivity leading to huge financial losses $[4,5]$. This is because $92 \%$ of the interruptions in the industrial sectors are due to power quality problems of voltage sag [6-8].

On the other hand, a small-scale electricity distribution network known as microgrid, connected with energy sources such as renewable energy, is combined with power electronics system in such a way that to provide electricity for a small community. Microgrid is a stand-alone controllable working power station consisting clusters of load and distribution generators. A typical microgrid operates in two modes i.e., a) a grid connected mode wherein the collaborative power is synchronized with the conventional grid and, b) an islanded mode in which the microgrid is operating independently to serve the power to a small community. A microgrid system is installed with distributed energy resources (DERs) such as hydro-turbine, photovoltaic or wind generators with immediate energy storage, loads, and power electronic converters $[9,10]$. 
This paper presents the microgrid consisting of dynamic voltage restorer (DVR) connected with the energy storage and hydro-turbine generator responding to the challenges in mitigating the power quality problems based on the standards stipulated in the IEEE 1159. The power quality definition and standards accentuated in the IEEE 1159 are, a) the percentage of total harmonic distortions (THDs) at the end-user should not exceed $5 \%$, b) voltage sag range is in decreasing limits to $10 \%-90 \%$ of the nominal value of the power frequency for a duration of half cycle to 1 minute, and c) voltage swell is in the increasing limits to $110 \%$ $180 \%$ of nominal at the power frequency for a duration of a half cycle to 1 minute $[11,12]$.

Power Quality Disturbances: Power quality plays an important role in maintaining the voltage, current and power within the permissible range and supplying it back to the consumers without any delay and interruption as stipulated under the IEC standards [13]. Hence, the utilities are deemed to provide quality services delivered to the consumers in a desired manner complying with several standards of voltage rating, frequency and reliability. Simultaneously, the end-user should able to utilize the delivered power in a desired and quality manners [2]. Power quality problems incurred in a distribution network can be categorized as (i) voltage fluctuation and flickering, (ii) harmonics, (iii) voltage sags, (iv) transients, and (v) grounding.

This signifies that the delivered power quality is the main concern for consumers, electrical generation and distribution companies, and researchers. Subject to the low emission and abundance of energy, renewable energy sources (RES), like solar and wind are widely used in a grid system with variety in its sizing. The power balance between the solar or photovoltaic systems and the power grid is thru the dc-bus voltage inverter controller. In particular, the dc-bus voltage inverter controller generates reference current values to ensure that the power generated by the photovoltaic array is injecting equal power to the grid and the power losses, so that the power balance could be attained $[14,15]$.

In most cases, the power quality problems that occur in a microgrid system connected with the RES are such as the reactive power compensation (RPC) and electrical harmonics pollution in distribution network in a microgrid instigated by the operation of power electronics devices [16]. The major power quality problems occur in a microgrid are such as, a) disturbances or harmonics in voltage, voltage sag/swell, unbalanced or flickering voltages, b) disturbances or harmonics in current, load reactive power, unbalanced or neutral current, impulse transient and interruptions.

Inverters for Power Quality Enhancement: Inverters are mostly used for medium and high-power applications. The multilevel inverters first introduced in [17] are most popularly used by researchers because it is capable to achieve higher output power quality, higher efficiency, low harmonic components, lower switching losses and lower $\mathrm{di} / \mathrm{dt}$ or $\mathrm{dv} / \mathrm{dt}$. Various control topologies and methods have been used for inverters to eliminate harmonics such as the selective harmonic elimination method (SHEM). However, SHEM is not suitable to be used in a real-time harmonic compensating application. Therefore, more advanced solutions were used nowadays for harmonic compensation applications. The most popular application used are active power filter and microgrid control, and online control method such as hysteresis band control. Power quality conditioning devices are used to enhance power quality of the system such as static compensator (STATCOM), distribution static compensator (DSTATCOM), active power filter (APF) and unified power quality conditioner (UPQC). However, there are advantages and disadvantages of each control methods, as mentioned above $[13,12]$.

\section{DYNAMIC VOLTAGE RESTORER}

Dynamic voltage restorer (DVR) is usually used to protect sensitive loads coming from the supply line such voltage sag/swell and other harmonics or disturbances. A typical DVR system has a voltage source inverter, controller for switching, DC energy storage device, output filter and an injection or coupling transformer [18] as shown in Figure 1.

In Figure 1, the operating principle of DVR is to detect and compensate voltage sags occurring in the supply hence shielding the sensitive loads from the power quality issues. DC energy source, injection transformer connected in series with distribution network and sensitive loads are parts of system configuration for the requirement of DVR installation. Batteries, supercapacitors, superconducting magnetic storage units and flywheels are the alternative options that can be used as the DC energy source. Voltage Sag occurs in the distribution network, is coming from the incoming supply. Once a fault is detected by the DVR, it is then compensated by injecting AC voltage generated from the DC power energy source through IGBT converter. Transformer feds the injected voltage into a distribution network to mitigate the voltage sag in order to maintain a power quality for the sensitive load [19].

Int J Pow Elec \& Dri Syst Vol. 10, No. 4, Dec 2019 : 2245 - 2253 


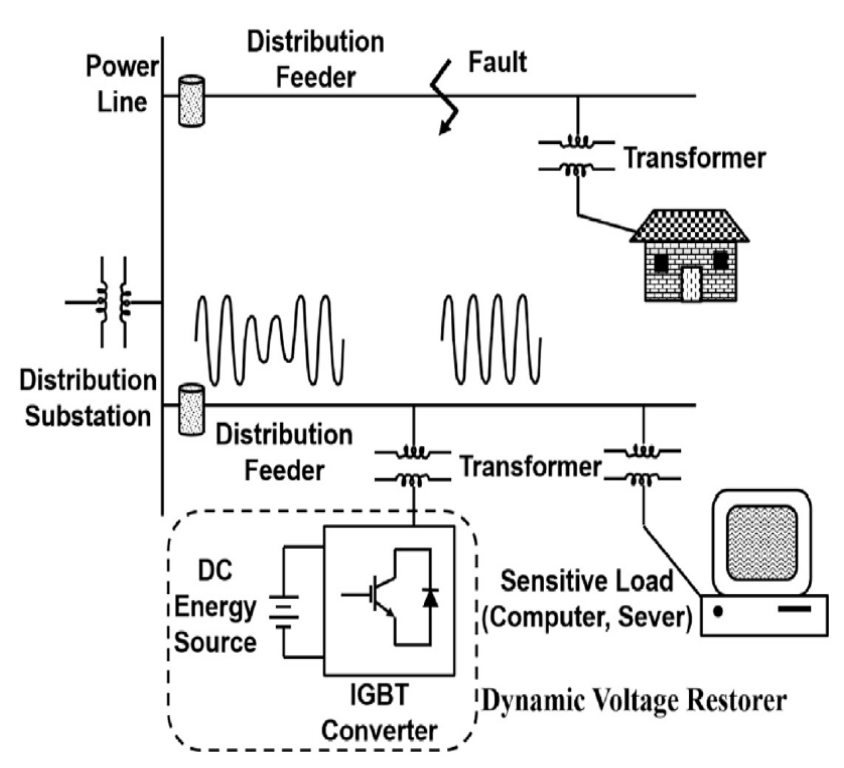

Figure 1. Operating principle of DVR [19].

\subsection{Working Principle of Series Active Power Filter}

Figure 2 and Figure 3 shows a combination of series active filter and passive filters for current harmonic compensation. LC passive filter can be connected in parallel to the load that impose high frequency impedance current path to compensate the current harmonics. Voltage regulation is corrected by compensating the fundamental frequency positive, negative and zero sequence voltage components of the distribution network [20]. In Figure 3, a small rating of passive filter is connected between transformer and inverter to suppress switching ripples. A control circuit, voltage controlled PWM inverter, and power semiconductor gate driver circuit are the main parts of series active filter [21]. The function of series transformer is to inject compensating voltage into a distribution network [22]. In Figure 5, a DC energy source can be used to supply real power compensation during the operation of DVR [23].

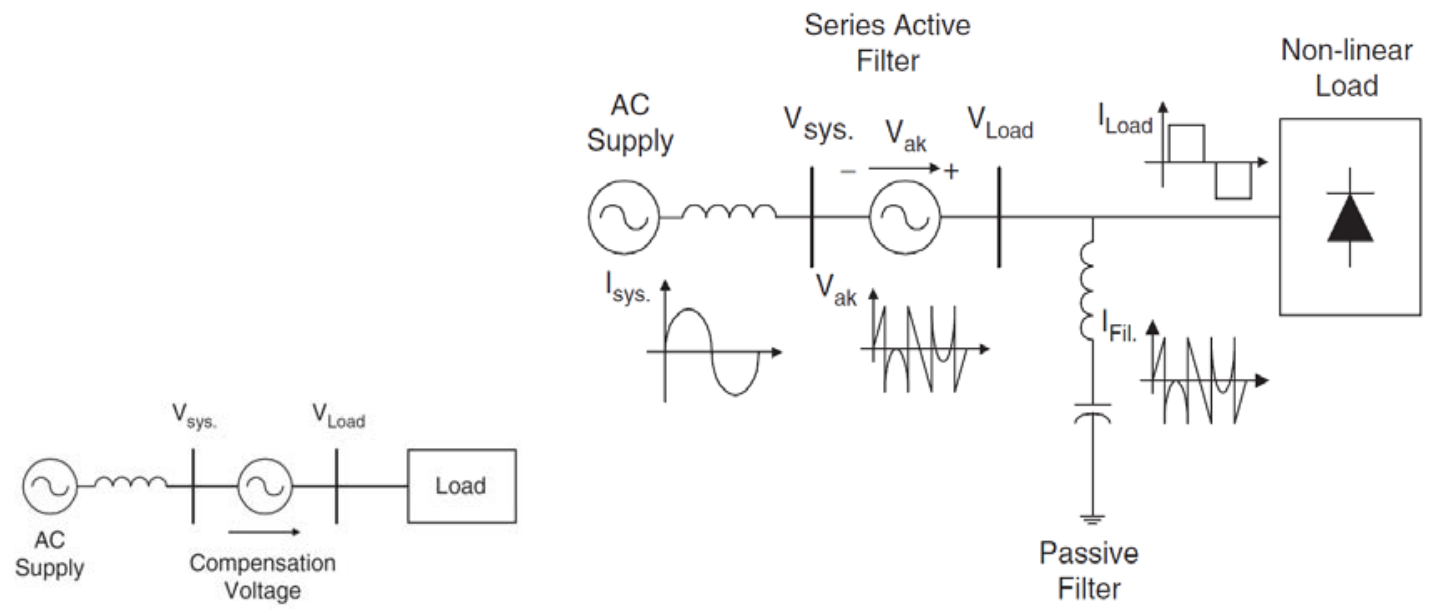

Figure 2. A voltage restorer: Series Active power Filter [20].
Figure 3. Series active power filter and passive filter combined in a one system [20].

In Figure 2, by applying the Kirchhoff's law, an AC closed circuit diagram for equvelent cirucit of series converter can be achived as shown in Figure 4 and the following methematical expressions is obtained [24].

Mitigation of power quality problems using series active filter in a microgrid system (Awais Farooqi) 


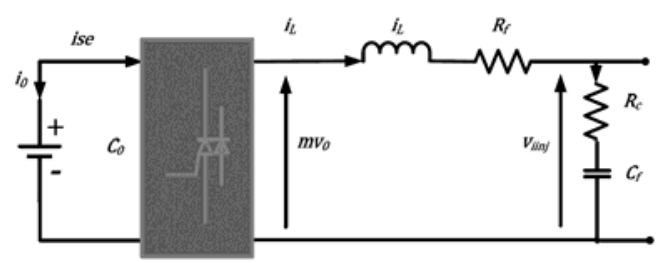

Figure 4. Equivalent circuit of series converter [24].

$$
\begin{aligned}
& m v_{0}=i_{L} R_{f}+L_{f} \frac{d i_{L}}{d t}+v_{i n j} \\
& v_{i n j}=i_{c} R_{c}+\frac{1}{c_{f}} \int\left(i_{c} d t\right)
\end{aligned}
$$

Where for series converter, $m=$ control input , $i_{L}=$ inductor current, $v_{i n j}=$ output voltage, $v_{0}=\mathrm{DC}$ link voltage, $L_{f}=$ filter inductance, $C_{f}=$ filter capacitance, $R_{f}=$ equivalent series resistance (ESR) of inductor, and $R_{c}=$ ESR of the capacitor.

\subsection{DVR combined with Mini-Hydro Turbine}

The block diagram of DVR connected to a microgrid system installed with the mini-hydro turbine is shown in Figure 5. In the proposed system, DVR is used for mitigating the unbalanced voltage compensation, distortions and sags coming from the supply line.

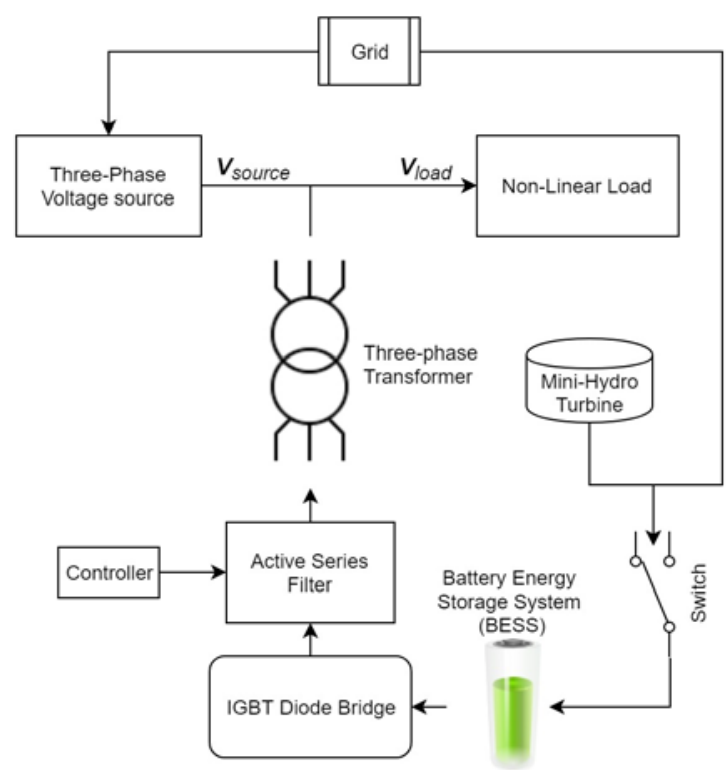

Figure 5. DVR utilized in a microgrid system installed with the mini-hydro turbine.

Figure 6 shows a complete system configuration wherein a three-phase AC voltage source is directly fed into the microgrid connected with a non-linear load. A three-phase PWM voltage-source inverter is connected in series with the input of microgrid through a three-phase coupling transformer required by an active series filter controller so-called as the DVR, designed to work on the following principles. That is to, a) detect imbalance voltage such as the sag, swell and harmonics at source side, b) produce a constant sine wave pulse at a constant amplitude to differentiate it with detected imbalances to extract reference voltage pulse, $V_{r e f}$, c) detect voltage waveform IGBT bridge output voltages, $V_{c}$, and d) compare $V_{r e f}$ with $V_{c}$ pluses in a hysteresis controller to generate input pulse for the commutation of gate input of controlled IGBT switches [25, 26].

Int J Pow Elec \& Dri Syst Vol. 10, No. 4, Dec 2019 : 2245 - 2253 
By applying the aforementioned technique, the DVR is able to compensate voltage across the primary transformer. Hence, a significant reduction in voltage harmonics at load can be acquired. At DC side of IGBT Bridge, a battery energy storage system (BESS) is used. The microgrid and mini-hydro turbine are connected to the BESS through a switch that keep changing its state depending on the current demand of energy or state of charge (SOC) cycle for the battery. When the hydro-turbine generation is greater than demand, the ideal switch closes to allow battery to start charging and vice-versa. In the BESS configuration, a SOC subsystem is implemented that opens only when the battery is reached close to SOC $=100 \%$.

The proposed microgrid system consists of renewable energy controller attached with battery charging controller system. Battery is connected to bridge as a DC source. The DVR with inverter is also connected to a three-phase transformer through a passive filter circuit. The three-phase AC transformer is connected between the three-phase AC source voltage and non-linear load passing through the microgrid connected control block.

\section{RESULTS AND DISCUSSION}

A microgrid system shown in Figure 6 highlights the performance of DVR connected with battery storage and mini-hydro turbine systems indispensable for mitigating voltage sags and swells.

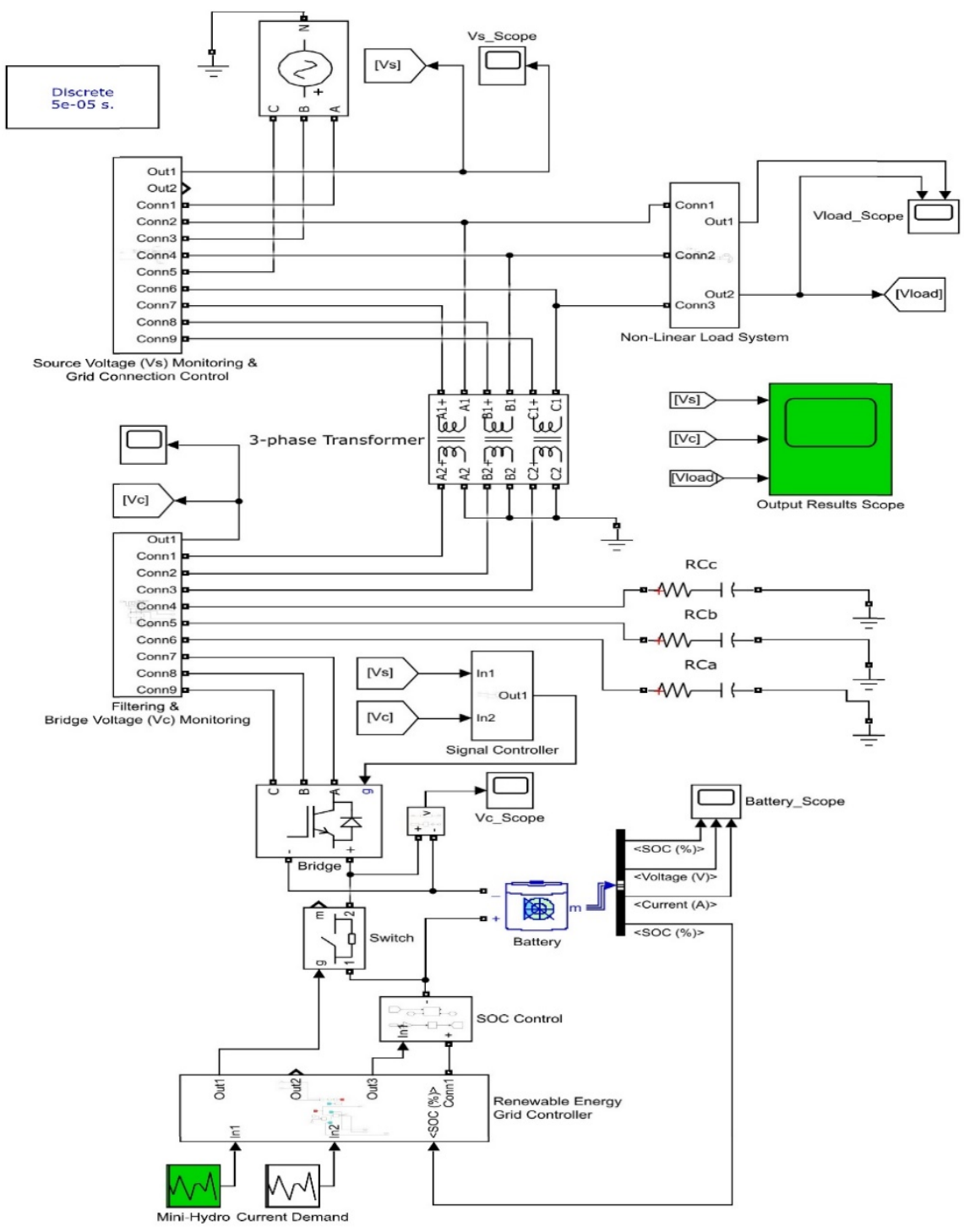

Figure 6. DVR System combined with battery storage and mini-hydro turbine systems. 


\subsection{Mitigation of Balanced Voltage Sag}

An equivalent short-circuit fault is exerted at the point of common coupling (PCC) yielding to a balanced voltage sag generated by switching on the impedance to the ground. Figure 7(a) shown in next page, the results of balanced voltage sag of $70 \%$ initiated from $\mathrm{t}=100 \mathrm{~ms}$ until $\mathrm{t}=350 \mathrm{~ms}$ at the PCC. The DVR voltage recovery mode begins as soon after the voltage loss is detected, as shown in Figure 7(b). Figure 7(c) shows an improved loading condition with mitigated balanced voltage sag confirming the robustness in the performance of DVR.
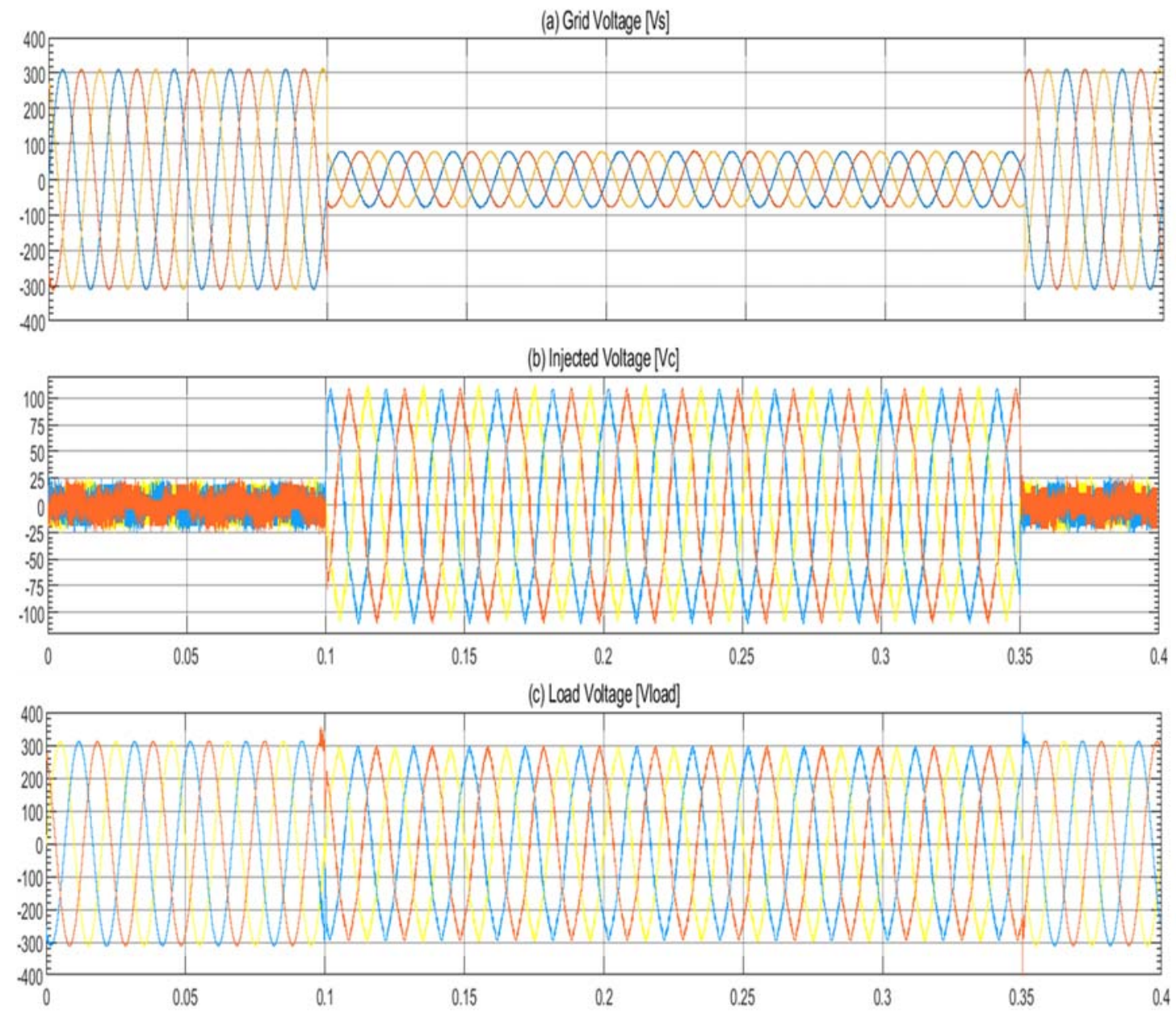

Figure 7: DVR in solving power quality problem with (a) balanced voltage sag of $70 \%$ at PCC, (b) voltage injected by DVR, and (c) improved loading condition galvanized by the mitigated balanced voltage sag.

\subsection{Mitigation of Balanced Voltage Swell}

In case of balanced voltage swells happened in the microgrid, the DVR should absorb the power from the grid. The standby mode of DVR is activated once the required energy is obtained from the battery connected with mini-hydro turbine system. However, absorption of power is very dangerous unless a power dissipation control system is installed that able to provide overvoltage protection to the microgrid [18].

Figure 8 (a) as shown in next page, explicates a $20 \%$ balanced voltage swell begins from $\mathrm{t}=100 \mathrm{~ms}$ till $\mathrm{t}=350 \mathrm{~ms}$ introduced at the PCC of microgrid. It can be observed that the DVR responded by injecting voltage with $180^{\circ}$ shift so that it is in phase to subtract the excessive voltage magnitude. However, once the voltage recovery is detected, DVR returns to standby mode to maintain a minimum conduction loss. Figure 8(b) shows the injected voltage required for balanced voltage swell mitigation. In Figure 8(c), the DVR is able to maintain the voltage peak closer to its rated value.

Int J Pow Elec \& Dri Syst Vol. 10, No. 4, Dec 2019 : 2245 - 2253 

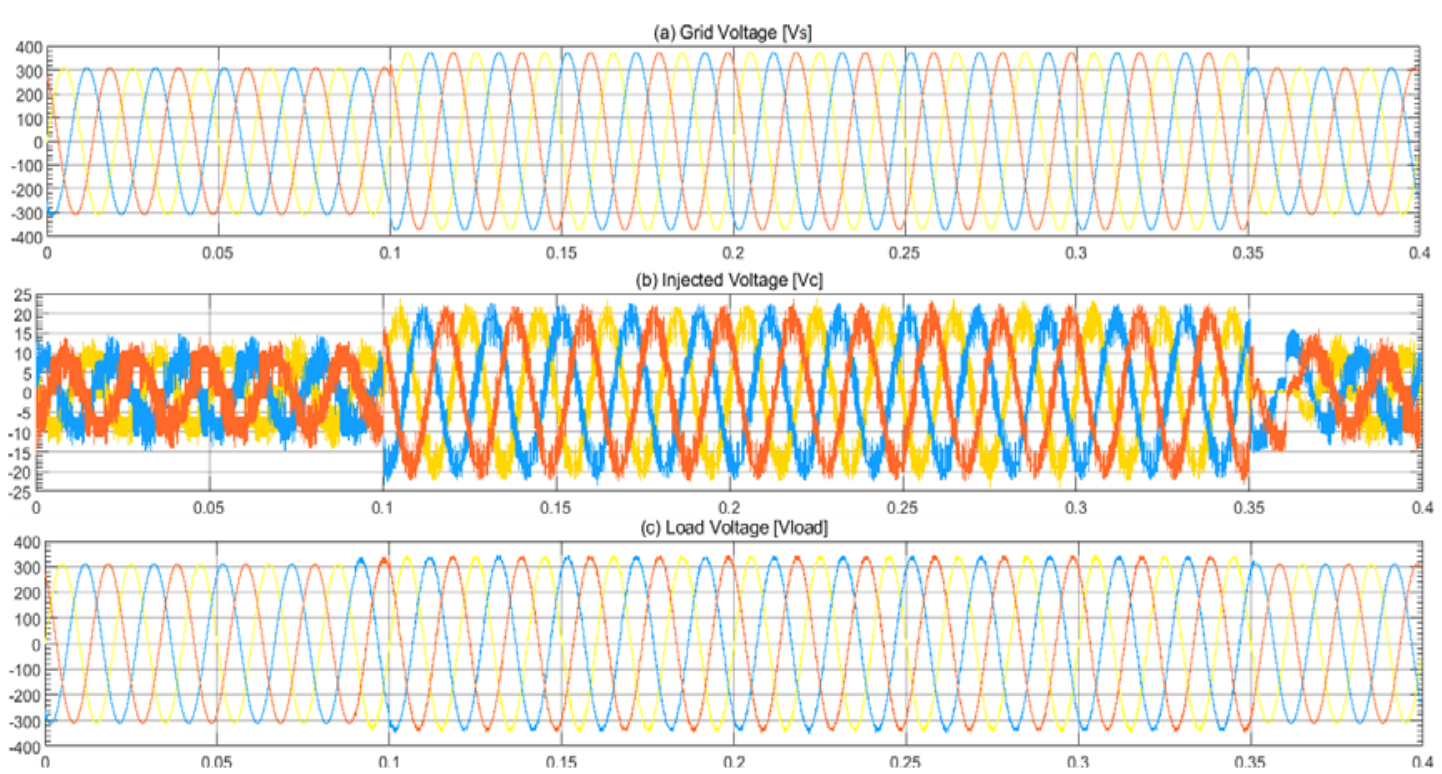

Figure 8: DVR in solving power quality problem with (a) balanced voltage swell of $20 \%$ at PCC, (b) voltage injected by DVR, and (c) improved loading condition galvanized by the mitigated balanced voltage swell.

\subsection{Minihydro Turbine System for Battery Charging System}

Figure 9(a) as shown in next page, depicts the discharging of battery during the operation mode of DVR. The battery capacity is 10Ah signifies that it can supply for system operation in 10 hours. In other cases, whereby the battery is charging from mini-hydro turbine system, its initial state-of-charge was set at $90 \%$. And Figure 9 (b) shows the charging curve rising from $90 \%$ at $\mathrm{t}=0 \mathrm{~s}$ to $91.6 \%$ at $\mathrm{t}=0.4 \mathrm{~s}$.
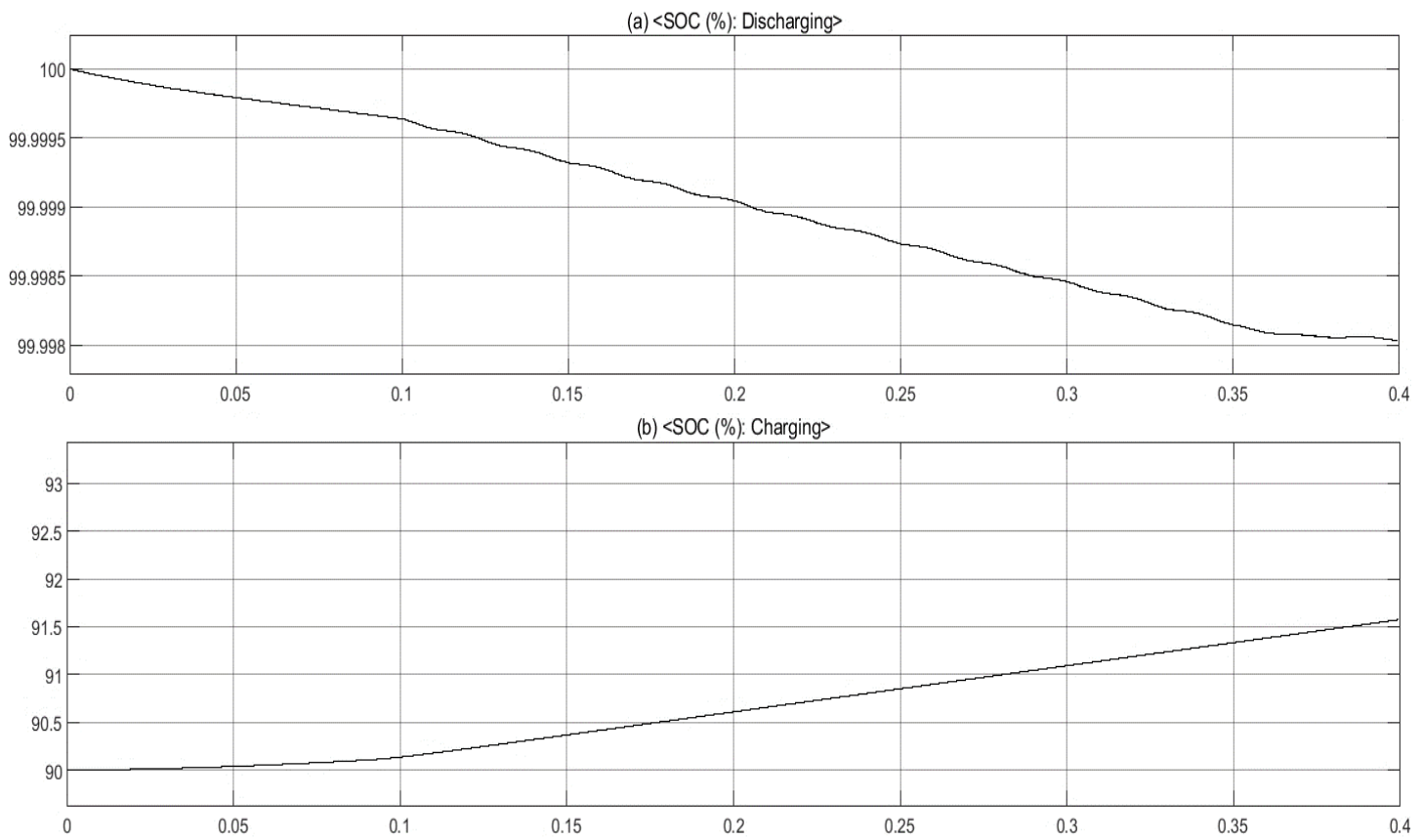

Figure 9. Battery SOC simulation with, (a) discharging of battery during DVR operation mode, and (b) battery charging from mini-hydro turbine system. 


\section{CONCLUSION}

This paper has discussed on the importance of DVR for mitigating the power quality problems in the microgrid connected with battery storage and mini-hydro turbine system. The results have shown that the higher percentage of voltage sag requires injecting a large DC voltage for mitigation. $70 \%$ of voltage sag requires the energy storage system to inject 224VDC into the microgrid system. This implies that it requires a battery management system to effectively deliver constant voltage during the discharging or charging of battery modes [27]. This is due to the fact that the battery initial state-of-charge that is less than $100 \%$, the voltage injection system is not able to deliver and sustain the required level of voltage injection. Furthermore, the proposed DVR technique can be considered as a highly reliable, effective and quick responsive device for power quality enhancement. It is also an effective device to protect sensitive loads for short period of time from sudden occurrence of voltage sags and swells. In the case study of DVR with mini-hydro turbine system, it is capable to operate under the scenario of renewable energy generation system.

\section{ACKNOWLEDGEMENTS}

This research was supported by the Long-Term Research Grant (LRGS), Ministry of Education Malaysia for the program titled "Decarbonisation of Grid with an Optimal Controller and Energy Management for Energy Storage System in Microgrid Applications" with project code 600-IRMI/LRGS 5/3 (001/2019). The authors would also like to acknowledge The Institute of Research Management \& Innovation (IRMI), Universiti Teknologi MARA (UiTM), Shah Alam, Selangor, Malaysia for the facilities provided to support on this research.

\section{REFERENCES}

[1] G. Tian, S. Wang dan G. Liu, "Design and realization of STATCOM for power quality improvement of wind turbine with squirrelcage induction generator," IEEE 7th International Power Electronics and Motion Control Conference - ECCE Asia, pp. 1985-1989, 2012.

[2] M. H. Rashid, Power Electronics Handbook, Canada: Academic Press, 2001.

[3] N. L. Ismail, H. D. M. Hidzir, S. Thanakodi, N. S. M. Nazar, P. Ibrahim dan C. K. M. S. C. K. Ali, "Modelling voltage sag mitigation using dynamic voltage restorer and analyzing power quality issue," in International Conference on Engineering and Technology (IntCET 2017), Putrajaya, 2017.

[4] Z. Z. Z. R. M. Y. M.M. Hussain, "Power loss estimation due to difference transformer tap changer position at interface," Journal of Fundamental and Applied Sciences, vol. 9, no. 3S, p. 2017, 2017.

[5] W. M. Dahalan, A. G. Othman, M. R. Zoolfakar, P. Z. M. Khalid dan Z. I. Rizman, "Optimum DNR and DG sizing for power loss reduction," Asian Research Publishing Network (ARPN) Journal of Engineering and Applied Sciences, vol. 11, no. 20, pp. 11952-11929, 2016.

[6] M. H. J. Bollen, Understanding power quality problems: Voltage sags and interruptions, New York: IEEE Press, 1999.

[7] S. W. Middlekauff dan E. R. Collins, "System and customer impact: considerations for series custom power devices," IEEE Transactions on Power Delivery, vol. 13, no. 1, pp. 278-282, 1998.

[8] S. S. Choi, J. D. Li dan D. M. Vilathgamuwa, "A generalized voltage compensation strategy for mitigating the impacts of voltage sags/swells," IEEE Transactions on Power Delivery, vol. 20, no. 3, pp. 2289-2297, 2005.

[9] Thomas Ackermann, Göran Andersson and Lennart Söder "Distributed generation: a definition," Electric Power Systems Research, vol. 57, pp. 195-204, 2001.

[10] M.T.L. Gayatri, D. A. M. Parimi dan A. P. Kumar, "Application of dynamic voltage restorer in microgrid for voltage sag/swell mitigation," IEEE Power, Communication and Information Technology Conference, 2015.

[11] IEEE. Std 1159-2009, "IEEE recommended practice for monitoring electric power quality," IEEE Standards, New York, 2009.

[12] IEEE Std 1547-2018, "IEEE standard for interconnection and interoperability of distributed energy resources," IEEE Standards, New York, 2018.

[13] M. Sharanya, B. Banakara dan M. Sasikala, "Dynamic voltage restorer and hybrid active power filter for power quality improvement," ARPN Journal of Engineering and Applied Sciences, vol. 13, no. 2, pp. 733-738, 2018.

[14] L. B. G. Campanhol, S. A. O. d. Silva, A. A. d. Oliveira dan V. D. Bacon, "Power flow and stability analyses of a multifunctional distributed generation system integrating a photovoltaic system with unified power quality conditioner," IEEE Transactions on Power Electronics, vol. 34, no. 7, pp. 6241-6256, 2019.

[15] A. B. Abdelkader, O. Abdelkhalek, I. K. Bousserhane, M. A. Hartani dan A. Omari, "PV integrated series active filter for sag voltage and harmonic compensation," International Journal of Power Electronics and Drive System (IJPEDS), vol. 10, no. 3, pp. 1255-1262, 2019.

[16] N. G. Hingorani, "Introducing custom power," IEEE Spectrum, vol. 32, pp. 41-48, 1995.

[17] A. Nabae, I. Takahashi dan H. Akagi, "A new neutral-point-clamped pwm inverter," IEEE Transactions on Industry Applications, vol. 1, no. 5, pp. 518-523, 1981.

Int J Pow Elec \& Dri Syst Vol. 10, No. 4, Dec 2019：2245 - 2253 
[18] D. Rajasekaran, D. S. S. Dash dan P. Vignesh, "Mitigation of voltage sags and voltage swells by dynamic voltage restorer," 3rd International Conference on Advances in Recent Technologies in Communication and Computing, pp. 36-40, 2011.

[19] B. J. Baliga, "Chapter 17 - IGBT Applications: Financial," in The IGBT Device Physics, Design and Applications of the Insulated Gate Bipolar Transistor, Oxford: William Andrew \& Elsevier Inc., 2015, pp. 561-581.

[20] M. H. Rashid, Power Electronics Handbook: Devices, Circuits, and Applications, Oxford: Elsevier Inc., 2011.

[21] S. P. Litrán, P. Salmerón, J. R. Vázquez dan R. S. Herrera, "Different control strategies applied to series active filters," in International Conference on Renewable Energies and Power Quality (Icrepq'07), Seville, 2017.

[22] S. Sahare dan S. B. Kudkelwar, "Power quality improvement using three phase series active power filter," International Journal of Advance Research and Innovative Ideas in Education (IJARIIE), vol. 3, no. 4, pp. 2558-2563, 2017.

[23] A. M. Saeed, S. H. A. Aleem, A. M. Ibrahim, M. E. Balci dan E. E. El-Zahab, "Power conditioning using dynamic voltage restorers under different voltage sag types," Journal of Advanced Research, vol. 7, no. 1, pp. 95-103, 2016.

[24] A. B. Abdelkader, O. Abdelkhalek, I. K. Bousserhane, M. A. Hartani dan A. Omari, "A comparative study and experimental validation on single phase series active power filter control strategies using pi, flc and sliding mode controllers," International Journal of Power Electronics and Drive System (IJPEDS), vol. 10, no. 2, pp. 731-743, 2019.

[25] M. M. Othman, N. M. L. F. N. Rakami, Z. A. Hamid, I. Musirin dan M. L. Othman, "Energy efficiency enhancement using dynamic voltage restorer (DVR)," International Journal of Power Electronics and Drive System (IJPEDS), vol. 10, no. 3, pp. 1308-1316, 2019.

[26] I. Annapoorani, R. Samikannu dan K. Senthilnathan, "Series active power filter for power quality improvement based on distributed generation," International Journal of Applied Engineering Research, vol. 12, no. 22, pp. 12214-12218, 2017.

[27] B. M. T. Lawder, B. Suthar, P. W. C. Northrop, S. De, C. M. Hoff, O. Leitermann dan M. L. Crow, "Battery Energy Storage System (BESS) and Battery Management System (BMS) for Grid-Scale Applications," Proceedings of the IEEE, vol. 102, no. 6, pp. 1014-1030, 2014. 